\title{
Leading Learning: Lessons from Successful Superintendency Teams
}

\author{
Jim Brandon ${ }^{1}$, Paulette Hanna ${ }^{2}$, Kent Donlevy ${ }^{1} \&$ Dennis Parsons ${ }^{1}$ \\ ${ }^{1}$ University of Calgary, Calgary, Alberta, Canada \\ ${ }^{2}$ Red Deer College, Red Deer, Alberta, Canada \\ Correspondence: Jim Brandon, University of Calgary, Calgary, Alberta, Canada.
}

Received: December 14, 2017

Accepted: January 10, 2018

Online Published: January 15, 2018

doi:10.20849/aes.v2i4.287

URL: https://doi.org/10.20849/aes.v2i4.287

\begin{abstract}
This collective case study provides insights into the ways that superintendents lead learning in six highly successful and learning focused school districts. Themes from our cross-case analysis generated five major assertions offered as lessons for superintendency teams: framing leadership research in action, leading learning through superintendency teams, building purposeful professional relationships, accessing external and internal expertise, and travelling the pathways of collaborative leadership learning. Evidence was collected through 23 focus groups and 16 individual interviews. In total, 114 educational leaders participated: 53 principals, 33 central office leaders, and 28 superintendency team leaders. Data from documents, artifacts, field notes, and an online survey were also gathered in pursuit of transferable insights for district leaders practicing in other settings.
\end{abstract}

Keywords: superintendents, instructional leadership, student success

\section{Introduction}

The focus of this study was on a broad conception of instructional leadership - leading learning - as practiced by educational leaders at the district level. Instructional leadership is often defined more narrowly in the literature than how we used the term in this report. Such narrow definitions generally focus on actions by principals that directly impact instruction (Hallinger 2003; Robinson, Lloyd \& Rowe, 2008). Fullan (2014) described this more narrow approach as direct instructional leadership. We aimed to better understand the wider range of leadership practices that are purposefully employed by district leaders with the intention of positively impacting teaching and learning in schools. Overall instructional leadership is the term Fullan (2014) used to describe this broader range of practices.

The purpose of our collective case study was to illuminate the overall instructional leadership practices of six school superintendency teams who have been identified as leaders of educator and student learning. To this end, we collected and analyzed qualitative data from 23 focus groups and 16 individual interviews that accessed the perspectives of 53 principals, 33 middle level district leaders, and 28 superintendency team leaders. We also gathered evidence from field notes, observations, and documentary sources. An online survey was also administered to 48 participants to augment the qualitative data in pursuit of a deeper and richer understanding of the following question: In what ways do successful superintendency teams lead educator and student learning?

Though findings presented in each of the six cases are important and will be of interest to both practitioners and policy makers, the primary purpose of this investigation was to yield insights into the phenomenon of overall instructional leadership in a more general manner, as practiced by superintendency teams in highly successful and learning focused school districts. Each case was studied to gain understanding of the complex meanings of this phenomenon in some of its situations (Stake, 2006, p. 41). In addition to uncovering particularistic and contextuality specific knowledge, we have sought to advance our understanding of district level instructional leadership with the goal of improving practice, policy, and theory (Andres, 2010, p. 10). Building on the findings and emerging themes from each individual case, our cross-case analysis identified nine larger themes. In turn, further analysis of these nine cross-case themes generated five major assertions about the ways in which successful superintendency teams lead educator and student learning. These five analytical generalizations are based on the research team's reasoned judgment and assertational logic about the extent to which the findings and themes of this study are transferable and can be used to guide superintendency team practice in other settings. 


\section{Context}

This section provides a brief description of the contexts in which the paper illustrates how superintendency teams lead learning in the following Alberta school districts: Chinook's Edge School Division, St. Albert Public Schools, Westwind School Division, Holy Family Catholic Regional Division, Fort McMurray Catholic Schools, and the Calgary Board of Education.

\subsection{The Alberta Educational System}

The province of Alberta is recognized as one of the world's most successful education systems (Alberta Education, 2011; Barber \& Mourshed, 2007; Barber, Whelan, \& Clark, 2010; Hargreaves, Crocker, Davis, McEwen, Sahlberg, Sumara, Shirley, \& Hughes, 2009; Hargreaves \& Fullan, 2012; Hargreaves \& Shirley, 2012, 2012a; Levin, 2010). Students in Alberta consistently score well on international assessments such as the Program for International Student Assessment (PISA) and Trends in International Mathematics and Science Studies (TIMSS).

Alberta's school system serves the province's 606,627 students in 1,868 schools organized into 62 school districts. The system employs 41,000 full and part-time teachers, each of whom is professionally prepared and provincially certificated in accordance with the provincial Teaching Quality Standard (Alberta Education, 1997). In addition to their university level teacher education, beginning teachers are only granted permanent certification on the recommendation of their school superintendents following two full years of successful teaching. Individuals wanting to become teachers need to have a Bachelor of Education or possess a recognized university degree supplemented by completion of a teacher preparation program leading to a provincially approved Interim Certificate.

Within Alberta's public school system, 135, 720 (22.3\%) of the students attend one of the 372 Catholic schools, $5565(1 \%)$ attend 34 Francophone schools, and another 7,547 (1.2\%) are enrolled in one of the 18 public charter schools operated by the 13 public charter school authorities. Public schools in the province are operated by 41 public, 16 Catholic and five Francophone publically elected school boards. Of the choices available to parents in the province, only $4 \%$ opt for private education (Alberta Education, 2012).

\subsection{Six Highly Successful School Districts}

The six school districts we selected for this study can be described as highly successful and focused on learning. As we explained in Section Three of this report, many Alberta school districts could be described in these ways. From a longer list of districts, we made our final determinations to gain insights from the perspectives of district and school leaders in a range of rural and urban settings, public and separate school boards, and a variety of geographic locations across the province. We further decided to focus on districts that had not previously been studied through research conducted through the support of the College of Alberta School Superintendents (Brandon, Hanna, \& Rhyason, 2013; Friesen \& Locke, 2010).

Table 1 presents a summary of key demographic information for each district in the order in which we gathered the data over the spring, summer, and fall of 2014: Chinook's Edge School Division, St. Albert Public Schools, Westwind School Division, Holy Family Catholic Regional Division, Fort McMurray Catholic Schools, and the Calgary Board of Education.

Table 1. District demographic information

\begin{tabular}{|c|c|c|c|c|}
\hline District & Students & $\begin{array}{l}\text { Teachers } \\
\text { FTE }\end{array}$ & Schools & $\begin{array}{l}\text { District } \\
\text { Notes }\end{array}$ \\
\hline Chinook's Edge School Division & 10,768 & 580 & 43 & $\begin{array}{l}\text { Large Rural } \\
\text { Central Alberta }\end{array}$ \\
\hline St. Albert Public Schools & 7,202 & 387 & 14 & $\begin{array}{l}\text { Small Urban } \\
\text { Edmonton Region }\end{array}$ \\
\hline $\begin{array}{l}\text { Westwind School Division * plus } 19 \\
\text { Hutterite Brethren schools }\end{array}$ & 4,326 & 248 & $13^{*}$ & $\begin{array}{l}\text { Small Rural } \\
\text { Southern Alberta }\end{array}$ \\
\hline $\begin{array}{l}\text { Holy Family Catholic Regional } \\
\text { Division }\end{array}$ & 2,165 & 158 & 9 & $\begin{array}{l}\text { Small Urban / Rural } \\
\text { NW Alberta }\end{array}$ \\
\hline Fort McMurray Catholic Schools & 5,482 & 315 & 10 & $\begin{array}{l}\text { Small Urban } \\
\text { NE Alberta }\end{array}$ \\
\hline Calgary Board of Education & 110,165 & 6,035 & 225 & $\begin{array}{l}\text { Large Urban } \\
\text { Calgary Region }\end{array}$ \\
\hline
\end{tabular}




\section{Conceptual Framework}

Evidence to support the claim that district leadership does play a significant role in improving student success student engagement, learning, and well-being - has been documented in an increasing number of recent studies. Of the research reports featured in our review of the literature, three are viewed as seminal studies that together provide a general overview of the most compelling evidence of school district leadership contributions to student success. Leithwood's $(2008,2010 \mathrm{a})$ meta-analysis of 31 published reports of high performing school district effects identified 12 common characteristics of such districts. Louis, Leithwood, Wahlstrom, and Anderson's (2010) massive study investigated school and district links to student learning over a six-year period. They underlined the importance the district leadership in four areas: setting direction, developing people, redesigning the organization, and managing the instructional program. The meta-analysis of school system leadership by Marzano and Waters (2009) provided substantive evidence that district leadership matters and "that when district leaders are carrying out their leadership responsibilities effectively, student achievement across the district is positively affected" (p. 5).

The Alberta Framework for School System Success (Brandon, Hanna, Morrow, Rhyason, \& Schmold, 2013) was founded on these three seminal studies of district leadership impact as well as additional current research in this same vein. It features 12 research verified leadership dimensions organized within four areas of collective practice as outlined in Table 2 below. Whereas each of the dimensions is a system leadership quality positively correlated to student learning, the four practice areas - vision and direction setting, capacity building, relationships and system design have been established to formulate a conceptually coherent structure for thinking and acting from the perspective of a district leadership team member.

Table 2. The Alberta framework for school system success

\section{Vision And Direction Setting}

Dimension 1: Focus on Student Learning

Dimension 2: Curriculum and Instruction

Dimension 3: Uses of Evidence

\section{Relationships}

\section{Dimension 7: System Connections}

Dimension 8: Parent - Community Engagement

Dimension 9: School Board Leadership

\begin{tabular}{ll} 
Capacity Building & System Design \\
\hline Dimension 4: System Efficacy & Dimension 10: System Alignment \\
Dimension 5: Leadership for Learning & Dimension 11: System Improvement \\
Dimension 6: Professional Learning & Dimension 12: Leveraging Technology
\end{tabular}

\subsection{Leading Learning at the District Level}

We were guided by research from a variety of sources, but organized within five Alberta Framework dimensions that we believed to be more specifically applicable to informing district instructional leadership practices: (a) a district wide focus on student learning (Framework Dimension One); (b) the alignment of curriculum, instruction, and assessment (Framework Dimension Two); (c) system efficacy (Framework Dimension Three); (d) expecting and supporting instructional leadership at the both the district and school levels (Framework Dimension Five); and (e) research informed approaches to professional learning (Framework Dimension Six).

In maintaining a clear chain of evidence our interview protocols and survey items were derived from the study's five-dimension conceptual framework (Yin, 2009). As a conceptual consolidation of specific district leadership practices that impact student outcomes, the framework was then used as an organizational guide for the coding, descriptive, and report writing processes we employed.

\section{Methodology}

We utilized a mixed method collective case study design to address the following research question: In what ways do successful superintendency teams lead educator and student learning? In keeping with mixed methods principles and assumptions, qualitative and quantitative methods were combined to provide a better understanding of the research problem and question than either method by its own (Creswell, 2012).

\subsection{Data Sources}

The rationale for using a mixed methods approach was to gain insights from both quantitative and qualitative 
data. The online survey that contributed to the cross-case analysis enhanced our triangulation efforts through anonymous data gathering from participants in four of the six districts. The qualitative interviews, focus groups, field notes, observations, documents, and artifacts allowed for a rich and in-depth exploration of perspectives in each of the six cases. Evidence was collected through 23 focus groups and 16 individual interviews. In total, 114 educational leaders participated: 53 principals, 33 central office leaders, and 28 superintendency team leaders

\subsection{Data Collection and Analysis}

Our collective case study focussed on six Alberta school districts as instrumental cases (Creswell, 2012) to illustrate and illuminate ways through which Alberta school superintendency teams lead educator and student learning. Evidence from multiple-case studies is "often considered more compelling, and the study is therefore regarded as being more robust" (Yin, 2009, p. 53) and is a "common strategy for enhancing the external validity or generalizability of your findings" Merriam (1998, p. 40). The determination of the six specific cases was purposeful in two major respects. First, we selected six school districts that could be described as "highly successful" and "focused on learning." In the province of Alberta there are many school districts that could be described in these ways. With the help of the Ministry of Education, we considered districts whose Annual Educational Results Reports showed strengths on three measures: (a) student achievement; (b) provincial survey results (on such factors as safe and caring environment, school satisfaction, and program quality); and (c) school completion rates.

Data collection and analysis in the six district cases were informed by collective case study or multicase methods (Creswell, 2012; Merriam, 1998; Stake, 1995, 2006; Yin, 2009). A case study is an in-depth exploration of a bounded system (e.g., activity, event, process, or individuals) based on extensive data collection (Creswell, 2007). "Bounded means that the case is separated for research in terms of time, place or some physical boundaries" (Creswell, 2012, p. 465). In collective case study, multiple are described and cross-referenced to better understand the phenomenon under investigation. The phenomenon investigated within the bounded system of the Alberta school system in 2014 was "school and district leader perceptions of the ways superintendency teams in successful and learning focused school districts lead educator and student learning". Such inquiry called for a range of research methods to do justice to the complexity of the case and to facilitate cross-case analysis and explanation.

Research team members traveled to each of the six districts to collect data through 23 focus groups and nine individual interviews. In total, 114 educational leaders participated in our inquiry: 53 principals, 33 middle level leaders, and 28 superintendency team leaders - including seven chief superintendents. The District and School Leader Survey asked participants to reflect on the 50 items related to district level instructional leadership from their perspectives as members of the superintendency team, central office leaders, or school principals. The purpose of surveys was in keeping with what Creswell (2012) described as an exploratory sequential mixed methods design, in which quantitative data is collected to help explain findings and themes from earlier collected qualitative data (p. 543). As with our qualitative data collection, participants were made aware of the voluntary nature of their involvement and their right to withdraw from the study at any time without penalty.

Yin (2009) contended, "mixed methods research can permit investigators to address more complicated research questions and collect a richer and stronger array of evidence than can be accomplished by any single method alone" (p. 63). The mixed methods component of our research design placed emphasis on the qualitative data, which was augmented by quantitative data during the cross-case analysis. The quantitative and qualitative data were then integrated during the final stages of data analysis, following processes outlined by Creswell (2012); Merriam (1998); Miles, Huberman, and Saldana (2014); and Stake (2006). In keeping with the requirements of case study research (Merriam, 1998; Stake, 1995, 2006; Yin, 2009), multiple sources of evidence were gathered and analyzed during our inquiry.

As a former school superintendent and two former deputy superintendents with more than 60 years of experience on senior leadership teams in five Alberta school districts, we have tried to transparently locate ourselves as researchers through all phases of this study. Our histories as district leaders positioned us as insiders in this research (Andres, p. 18). From this position, we were able to gain access to school district personnel, documents, and artifacts quite readily. Through our vantage points as experienced members of the superintendency and as career long advocates of overall instructional leadership we were able to continuously collect, analyze, and interpret data through the lens of our professional experiences. As researchers who have transitioned away from the daily life worlds of practicing educational leaders and into the academic and consulting domains, we were also positioned as outsiders in this research. From this vantage point, we were consciously committed to adhering to the principles of mixed methods and collective case study research. 


\section{Emerging Themes}

Descriptions of each superintendency team's efforts to lead educator and student learning are presented in the larger report upon which this paper is based (Brandon, Hanna, \& Negropontes, 2015). In accordance with the collective case study research design, the six case portraits were constructed from a careful analysis of multiple evidence sources examined. In each instance, our descriptions are organized within a five part conceptual framework derived from a critical review of the literature on school district leadership effects. Key findings and emerging themes conclude each of the six individual cases presented in the larger report.

\subsection{Cross-Case Themes}

Though the insights provided in each of the six cases are important and will be of interest to both practitioners and policy makers, the primary purpose of this investigation was to enhance our understanding of the phenomenon of overall instructional leadership as practiced by superintendency teams in highly successful and learning focused school districts. Individual cases were studied to gain understanding of the complex meanings of this phenomenon in some of its situations (Stake, 2006, p. 41). Each case summary illuminates one contextualized set of approaches used by a superintendency team in its specific geographic, social, economic, and educational setting. Building on the findings and emerging themes from these individual illustrations, our cross-case analysis identified the nine larger themes that are the subject of this report section. Assertions and transferable insights arising from these themes will be presented in the next and concluding section.

In accordance with the principles and assumptions of mixed methods research the qualitative and quantitative data were combined to provide a better understanding of the research problem and question than either method alone (Creswell, 2012). The nine major themes discussed below are based primarily on our further analysis of the qualitative data. To augment cross-case findings derived primarily from the interview data, we analyzed responses to the District and School Leader Survey completed by 48 of the 77 possible participants in four of the six school districts. We do not claim that the results from this non-probalistic (purposive and convenient, but not random) sample are statistically generalizable. However, the survey results do serve the purpose of helping to explain and to illustrate findings and themes from earlier collected and analyzed qualitative data.

Though this cross-case theme development process was ongoing and continuous over the entire course of the study, early in our investigation we began to identify and discuss commonalities among the cases and to generate a list of possible themes. In a second stage, one team member took the lead in formalizing and describing the cross-case themes following data collection from all six settings. In stage three, a second researcher reviewed the surveys and began blending the two data sources. In stage four, selected research literature was consulted to deepen our understanding of the mixed data and to aid our interpretations and assertions. All of us were engaged in critically reviewing the analysis as it evolved into findings, themes, and assertions.

Further evidence of the utility of the five dimensions of the Alberta Framework that served as our conceptual framework (Table1) is provided in the first five of the cross-case themes. Our research benefitted from the use of this conceptual lens from the design of interview and survey questions, through the collection of both sets of data, and into the analysis and interpretation phases. The ways we utilized our conceptual framework acknowledges Merriam's (1998) observation: "In multicase or cross-case analysis, the use of predetermined questions and specific procedures for coding and analysis enhances the generalizability of findings in the traditional sense" ( $\mathrm{p}$. 208).

During the individual and focus group interviews we took note of how well versed principals, middle level leaders, and superintendency team members were in current research literature. Almost every educational leader we encountered was able to speak passionately and eloquently about a wide range of credible evidence informed leadership practices. What was even more impressive was their orientation to action. It is one thing to know what should be done; it is quite another challenge to move evidence informed ideas into sustained action. Most of the school and district leaders we encountered were striving to practice in ways that were framed by what they judged to be contextually appropriate best available evidence.

As we engaged with the participants and analyzed the data, it became apparent that the role of the Alberta Framework was significant, if not always consciously so. Many aspects of this document were reflected in the language and actions of district leaders. This alignment may be related to the engagement of some members of the superintendency teams in the development of the framework and related professional learning opportunities over the previous seven years, the availability of the CASS publication of the framework to all superintendency team members or other related research based professional learning opportunities.

Cross-case themes six through nine are based on findings that do not fit neatly within the Alberta Framework. These final four themes illuminate district leadership practices that are not specifically delineated in our conceptual framework. Themes six through nine speak to the overwhelmingly positive impact of learning-oriented 
relationships and collaborative leadership at the district level.

\subsubsection{Theme One: Focusing on Student Success}

Participants in all six settings articulated that their districts were highly focused on student success: learning, engagement, and well-being. Educators at every level indicated that their work was guided and in many cases, inspired, by a clear learning vision that was understandable, attainable, and forward looking. The learning direction encouraged educators to help improve life chances for all students.

Our first cross-case theme underlines the benefits of intentionally focusing district energy and efforts on teaching and learning. The senior leaders in this study were committed to developing and acting on a widely shared vision and focus on student learning and well-being in the $21^{\text {st }}$ Century. In this respect, the work of the six superintendency teams aligned with and added to research claims that leadership practices aimed at creating a such a widely shared sense of purpose can have a significantly positive impact (Elmore \& Burney, 1999; Darling-Hammond, et al., 2003; Friesen \& Lock, 2010; Hightower, 2002; Leithwood; 2008, 2010a, 2011, \& 2012; McLaughlin \& Talbert, 2003; Togneri \&Anderson's, 2003; Wahlstrom, Louis, Leithwood, \&Anderson, 2010a, 2010b). The theme also supports the need for attention to be placed on engaging students intellectually, academically, and socially to more fully support student learning and welfare for the immediate and longer terms (Willms, Friesen, \& Milton, 2009).

\subsubsection{Theme Two: Enabling Engaging Instruction}

Many of the senior teams called upon principals, learning coaches, learning leaders, and central office leaders to invest heavily in teaching strategies designed to more deeply engage all students. Holy Family is consolidating professional learning about teaching and learning, rather than continually engaging in new initiatives. The intent is to sustain support to schools in their efforts to increasingly provide highly engaging forms of instruction to all students. The five principles of Friesen's (2009) Teaching Effectiveness Framework are being extensively utilized across the Calgary Board of Education to support collaborative teacher efforts to design learning tasks that more consistently engage students in worthwhile and engaging work. Figure 5.4 indicates that movement in this direction is evident and increasingly well implemented.

\subsubsection{Theme Three: Fostering Collective Efficacy}

Consistent with the direction charted by existing research, each of the senior leadership teams provides quite extensive opportunities for staff to develop expertise relevant to achieving the district's goals. Steering committees for initiatives; professional learning community groups; one on one meetings of principals with the superintendent; the administrators retreat with the Board every two years; district organizational health committee; long service awards; professional development, including book studies and in-basket activities and administrators council are all examples of the variety of structures in place in St. Albert Public to engage and to build capacity and collective capacity.

The data that generated cross-case theme three were extensive and varied. The structures and norms deliberately established in the districts have produced a continuum of interconnected school and system leader networks wherein educators work together toward achievement of the system's goals. Bandura $(1977,1986,1989,1997)$ provided the research foundations that explain the persistence in solving problems and effortful responses to challenges that we heard about through our focus groups and are characteristic of individuals and staffs with high levels of efficacy. Leithwood's $(2008,2010 \mathrm{a})$ and his colleagues $(2010,2012)$ found that a sense of collective efficacy on the part of a district's principals was a significant factor in accounting for district effects on student achievement. The way that the districts in our study built collective efficacy run parallel to what Leithwood, Anderson and Louis (2012) found. Districts contribute most to school leaders' sense of efficacy through five strategies: (a) unambiguously assigning priority to the improvement of student achievement and instruction; (b) investing in the development of instructional leadership; (c) ensuring that personnel policies support the selection and maintenance of the best people for each school; (d) emphasizing teamwork and professional community; and (e) providing worthwhile programs of professional development, aimed at strengthening their capacities to achieve shared purposes (p. 119).

\subsubsection{Theme Four: Scaffolding overall Instructional Leadership}

Quite a volume of data related to theme four came forward through their early entries into the conversations. Participants from all levels were eager to describe school and district approaches to this work. Participants at every level viewed this as the core work of the district leadership team.

In addition to the qualitative evidence we gathered that showed that the senior leaders in this study were persistently focused on student engagement, learning, and well-being, the survey results displayed in Figure 2 are a further indication of the instructional leadership focus of the superintendency teams. 
Our discussion of the ways in which this emphasis on instructional leadership was played across the cases follows the three specific interview protocol questions. In each instance survey and qualitative data are combined. When examined together, Figures 1 and 2 provide additional and quite compelling evidence about the strength of superintendency team commitment of overall instructional leadership in the cases. On both measures, ninety-five percent of participants indicated that senior leaders were both focused on instructional leadership and have similar expectations for school leaders. That is, principals and assistant principals are expected to be familiar with and supportive of the classroom work of their teachers.

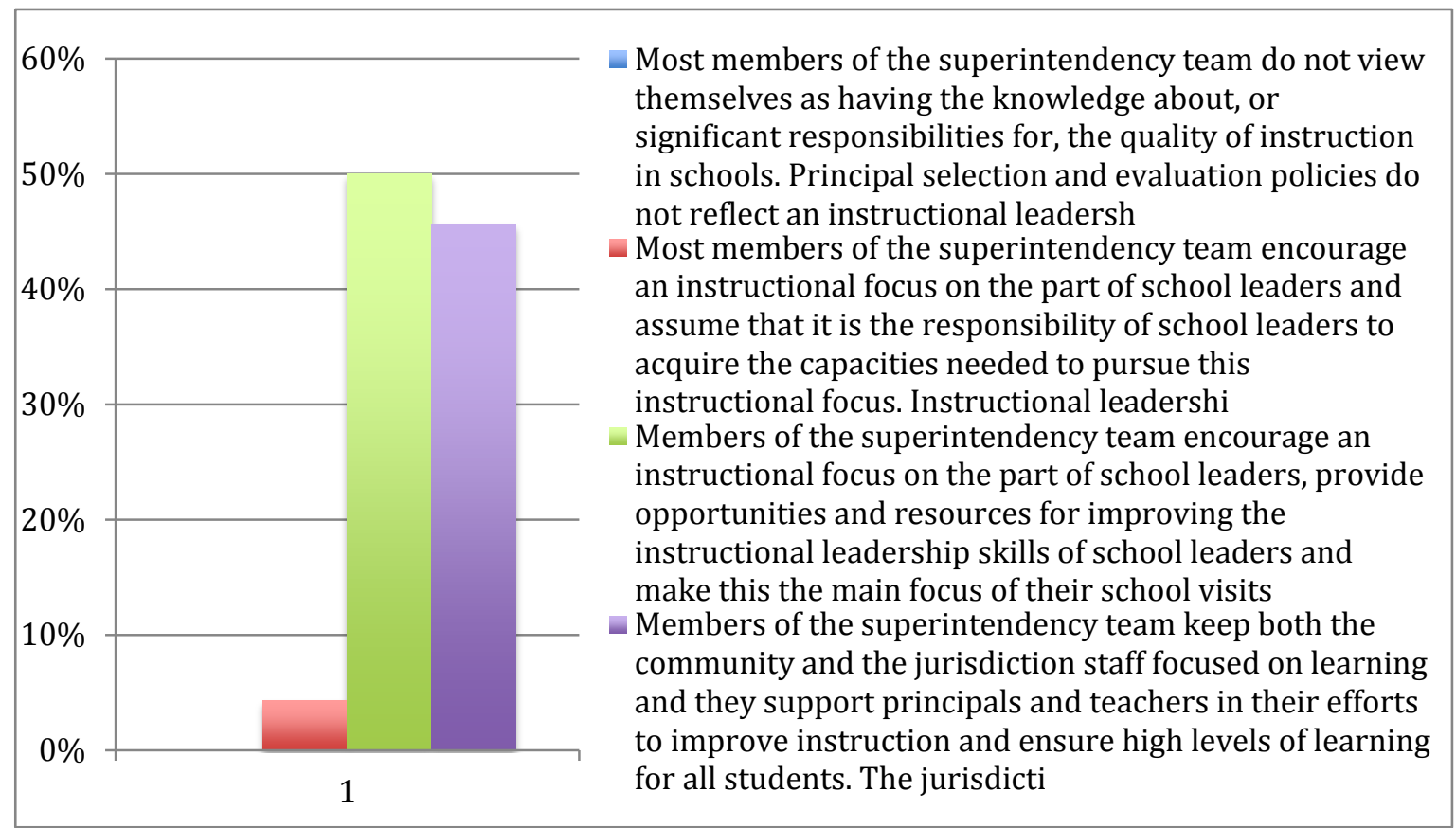

Figure 1. Superintendency team's focus on instructional leadership

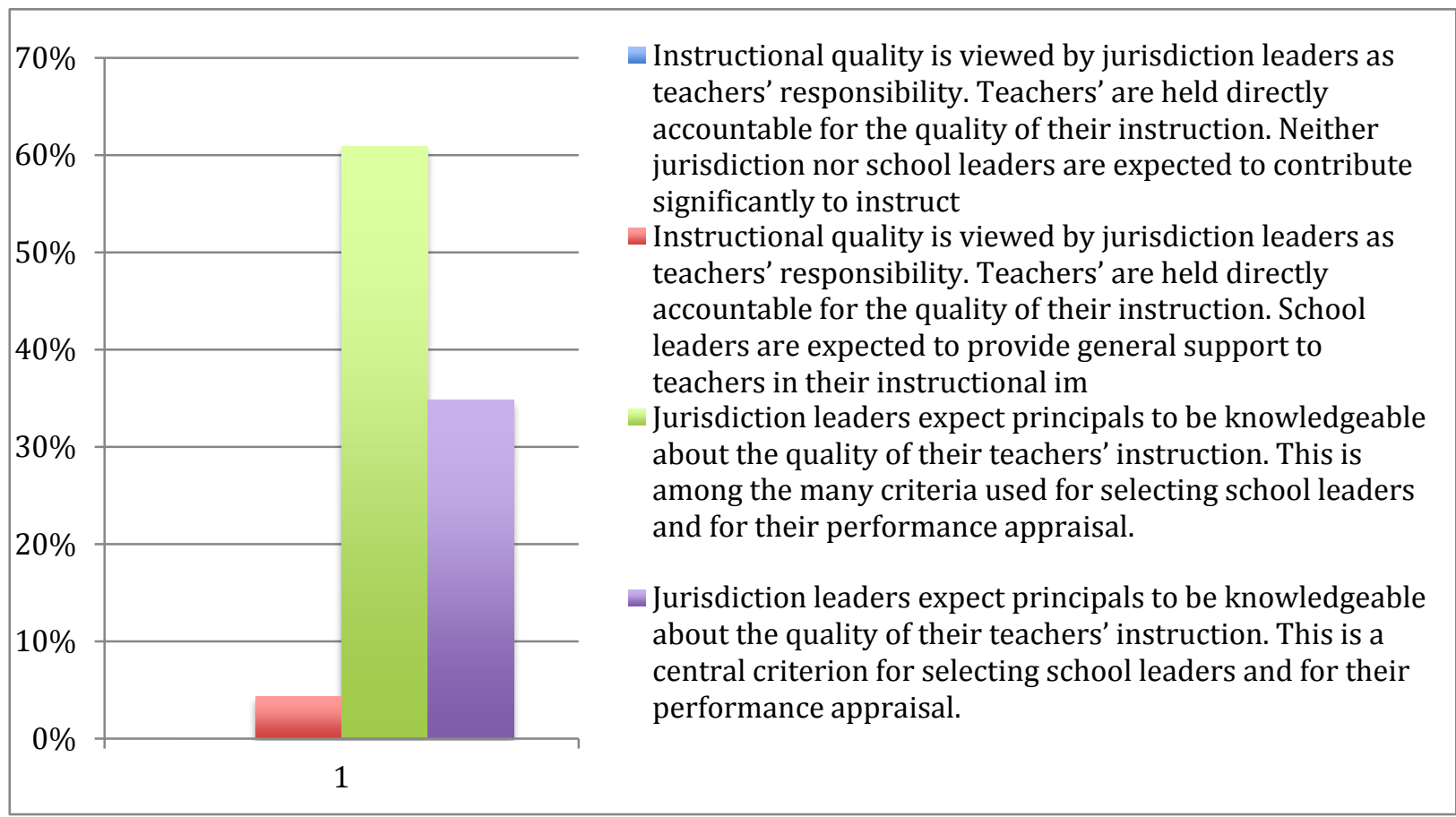

Figure 2. Holding principals directly accountable for instructional quality 
The expectation that principals will be knowledgeable about the quality of their teachers' instruction was universally understood and applied in all six districts. These expectations played out in nuanced ways in each system. Holy Family and Fort McMurray Catholic, for instance, expect principals to spend a specified percentage of their time in classrooms. Westwind, St. Albert, and Chinook's Edge have similar expectations, but take a more general approach. In all these cases, the intention is to create relationships of expectation and support within schools. Interactions with teachers are often structured around questions such as "How is this making a difference for student learning? What can we do to help?" CBE they indicate that they are expected to be knowledgeable of the quality of their teachers' instruction. In addition, each principal viewed "leading teacher learning" as an important part of the role.

Cross-case theme four-scaffolding overall instructional leadership - illustrates how persistent senior leader commitment to the development of instructional leadership is progressing in the six district settings. To a considerable degree, the efforts of district leaders in our study aligns with the growing research base of how school districts can do this important work well (Anderson \& Louis, 2012; Barber, Whelan, \& Clark, 2010; Louis \& Wahlstrom, 2012; Robinson, 2011; Robinson, Lloyd, \& Rowe, 2008, Togneri \& Anderson, 2003; Wahlstrom, 2012). Increasingly, these leaders are working to improve instructional leadership practices in what Wahlstrom (2012) found to be two complementary categories: Instructional Ethos and Instructional Actions. These leaders are working broadly to build professional community to generate benefit through the establishment of school and district cultures that support continual professional learning. At the same time, they are working to enhance school leader capacity to supportively engage with individual teachers to promote professional growth in classroom settings.

\subsubsection{Theme Five: Strengthening Professional Learning}

The qualitative evidence collected in the six districts underlines the high value placed on professional learning. At both the district and school levels, most of the time spent on professional learning was clearly aimed at enhancing and supporting teaching and learning. These senior leaders were acting on Firestone and Riehl's (2005) conclusion that: "districts play a key role in supporting instructional reform by being the primary designers and deliverers of learning opportunities for teachers, and if they do so in a focused, coherent fashion they can influence teaching practice" (p. 316). Figures 3 and 4 illustrate aspects of this theme.

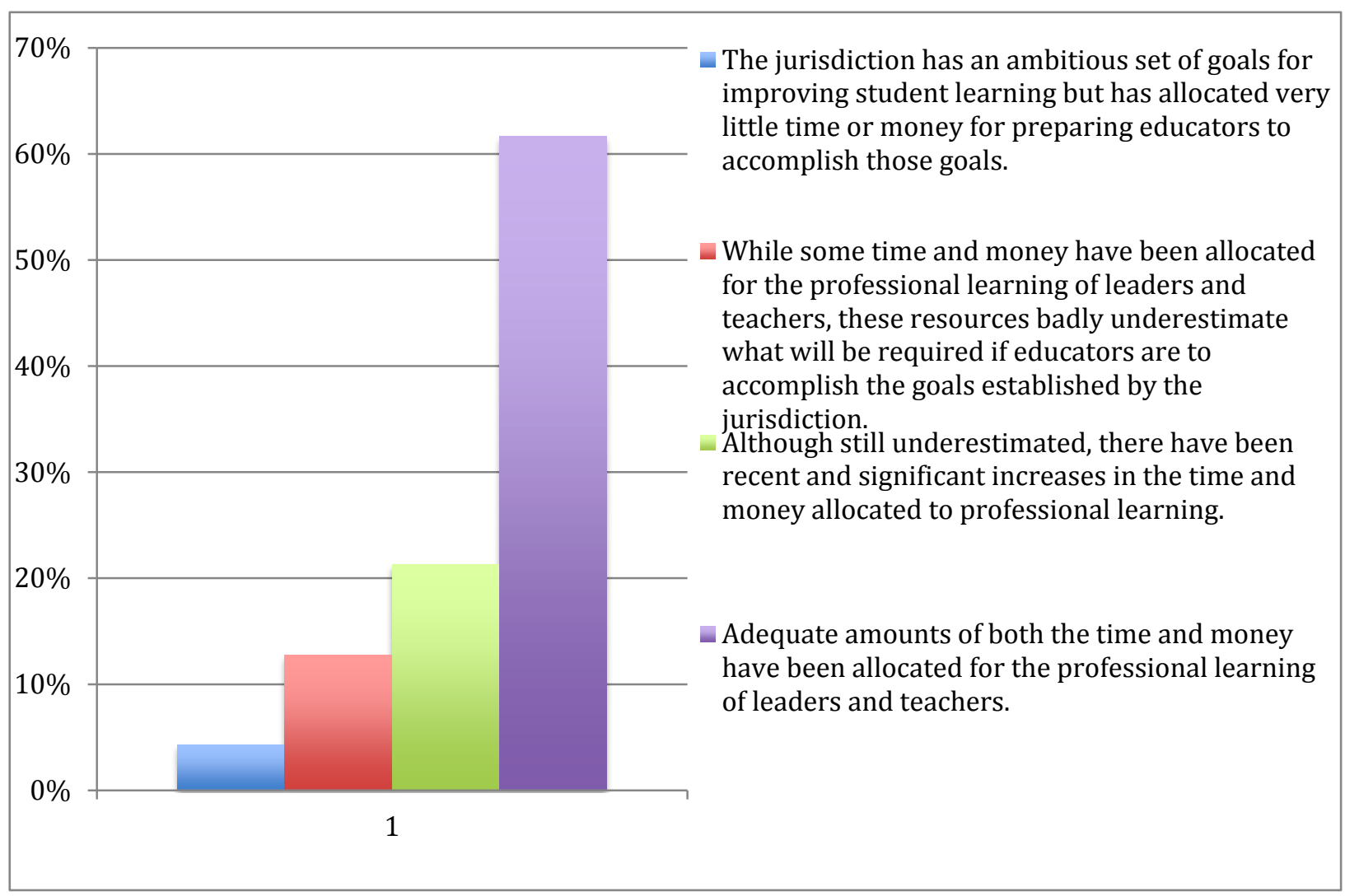

Figure 3. Time and money allocated to professional learning 


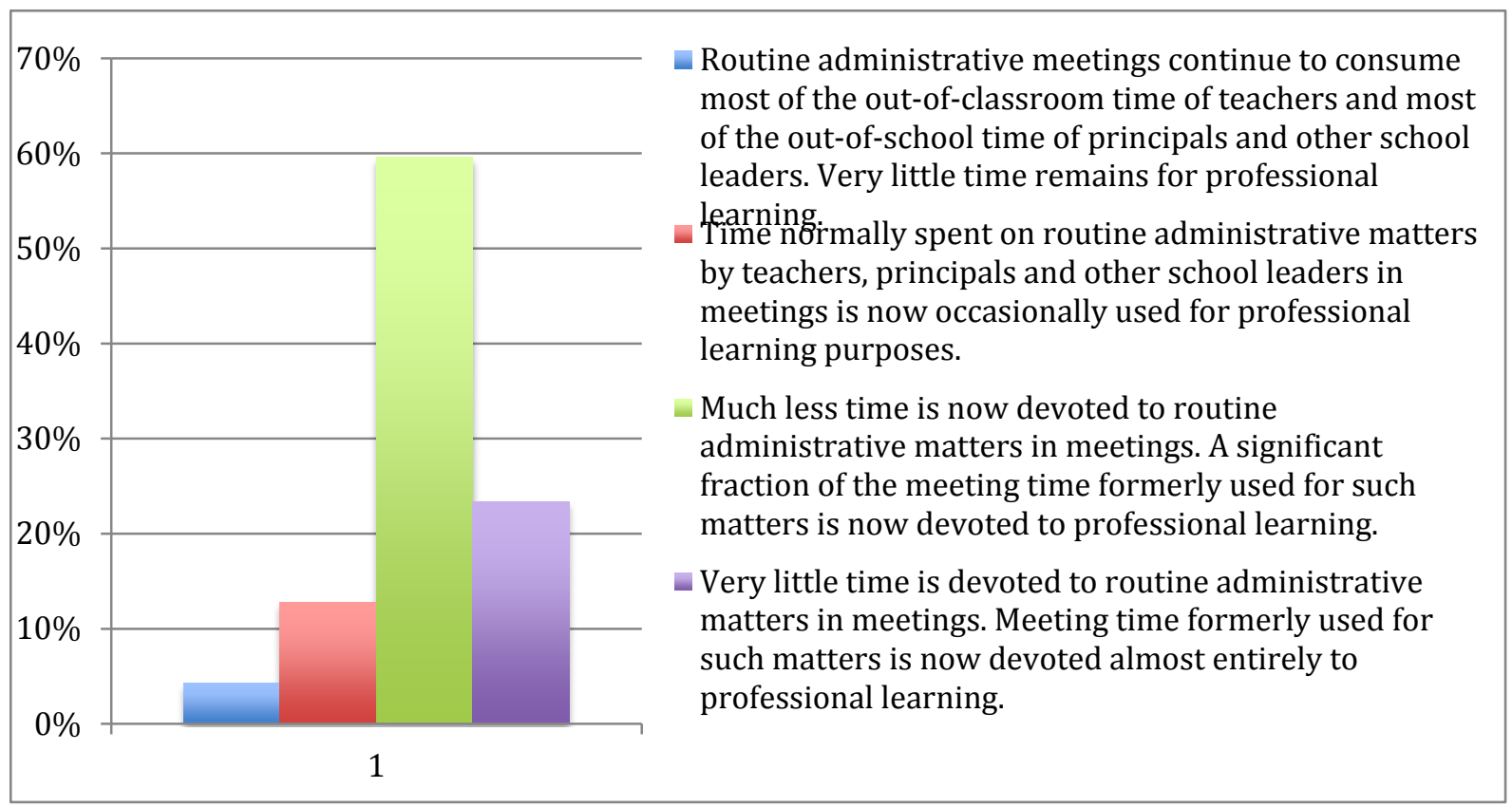

Figure 4. Refocusing routine institutional practice to serve professional learning

Cross-case theme five - professional learning - underlines the benefits of intentionally focusing district resources on building teaching and learning capacity through effective professional learning. District leaders in this study were committed to ongoing and sustained educator learning. In several instances, their efforts reflected current research how to effectively improve leading and teaching practice through focused and responsive professional learning. In other cases, intentions were good, but approaches were less tightly connected to the research. Evidence supporting the importance of professional learning was claimed in 21 of the 33 studies reported in Leithwood's $(2008,2010 \mathrm{a})$ review. This was the largest number of studies reporting evidence about any of the 12 dimensions of high-performing districts. We expect to a continuing evolution toward the more evidence driven professional learning, as identified in an increasing number of studies (Bredeson and Johansson, 2000; Firestone \& Riehl, 2005; Leithwood 2008, 2010a; Opfer, Pedder, \& Lavicza, 2007; Pritchard \& Marshall, 2002; Timperley, 2011; Timperley, Wilson, Barrar, \& Fung, 2007).

\subsubsection{Theme Six-Leading Learning through Superintendency Teams}

Theme Six-Leading Learning through Superintendency Teams is one of the fundamental ideas that have run through our study from conception to execution. From our past experiences working as members of senior leadership teams in five Alberta districts, we had a strong, shared faith in the importance of team leadership and team learning grounded in the literature by Senge (1990). The significance of the district leadership group working as a team in their collective efforts to lead educator and student learning became increasingly prominent during each successive data collection visit. 


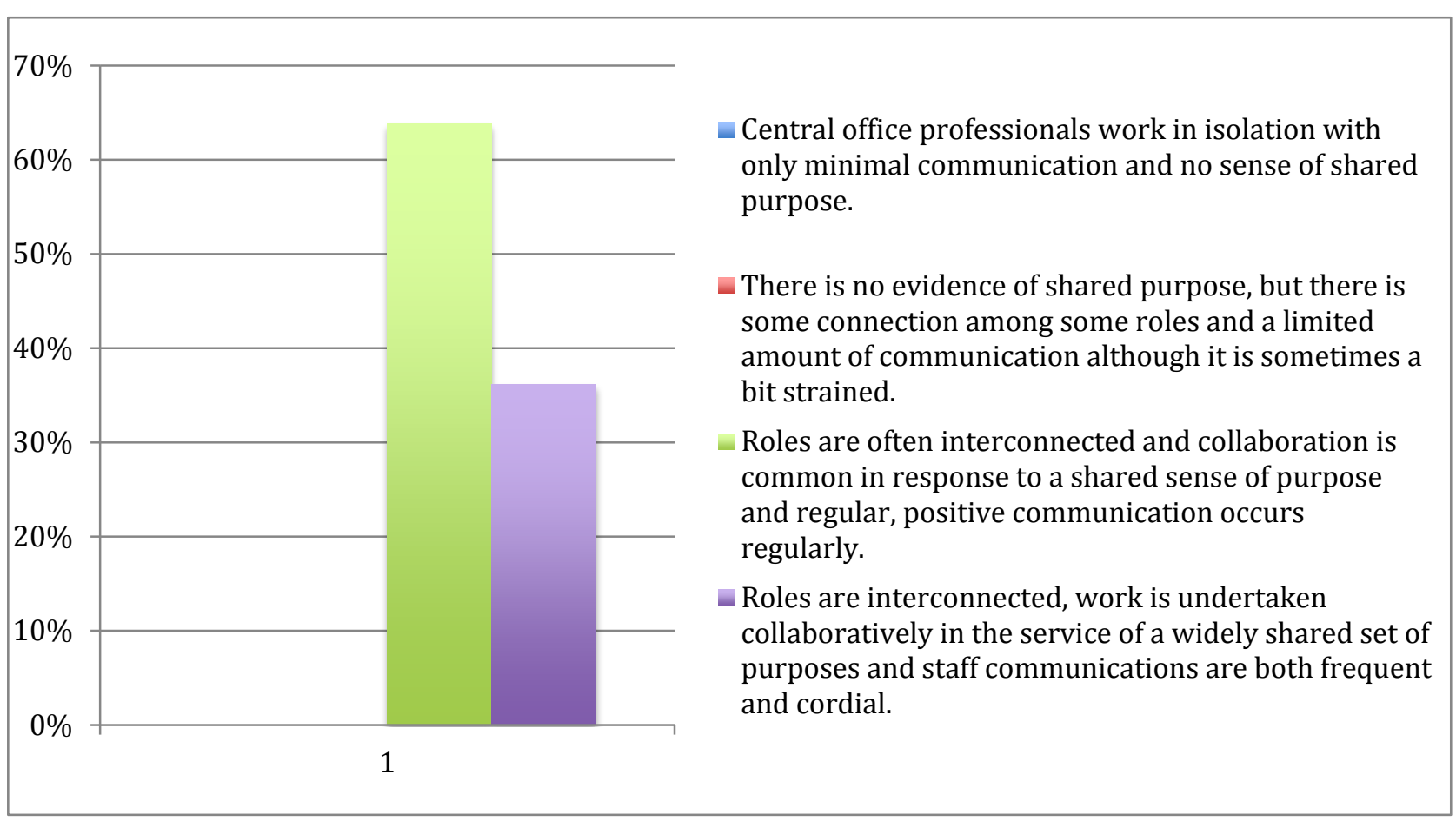

Figure 5. Relationships and sense of community among central office leaders

Superintendency teamwork was seen by participants to contribute to student success in a number of ways. Under the overall leadership of the superintendent, central leadership teams in these districts were working together to establish and support clear expectations for school leadership practice. They coordinated organized opportunities for teachers and principals to engage in relevant and targeted professional learning that connected to the strategic focus of the district. Participants repeatedly noted that the most significant focus of the superintendency teams was on student learning and achievement. All participants viewed this as the core work of the district leadership team. The survey results portrayed in Figure 5.16 are indicative of this perspective.

Under the overall leadership of the superintendent, central leadership teams in these districts were working together to establish and support clear expectations for school leadership practice. They coordinated organized opportunities for teachers and principals to engage in relevant and targeted professional learning that connected to the strategic focus of the district. Participants repeatedly noted that the most significant focus of the superintendency teams was on student learning and achievement. All participants viewed this as the core work of the district leadership team. The survey results portrayed in Figure 5 are indicative of this perspective.

The unique role of the Chief Executive and Chief Educational Officer in each district was quite well understood and very much appreciated as a distinct and challenging position by all participants. What was even more greatly appreciated was the way in which the superintendents in this study were working with their senior leadership colleagues to provide coherent, coordinated, and focused leadership of the learning agenda in the districts. Their work in this regard is linked with evidence in a number of recent studies (Louis \&Wahlstrom, 2012; Wahlstrom, 2012; Wahlstrom, Louis, Leithwood, \&Anderson, 2010a, 2010b). Leithwood's (2010) second CASS sponsored research study of district improvement processes concluded that the district leadership team is the single most important influence on district turnaround processes and that the superintendency team should be held directly accountable for tasks it is uniquely positioned to accomplish (p. 28).

\subsubsection{Theme Seven: Building Purposeful Professional Relationships}

In addition to what participants said about the nature of educator relationships within the district using such terms as-open, supportive, trusting, and reciprocal-we also formed our own thoughts in this direction through reflection on and dialogue about each of our data collection visits. With very few exceptions, participants were cordial, relaxed, and proud to be engaged with each other in conversation about the ways in which they were working together with their colleagues at various levels to support teacher and student learning. It was clearly and consistently evident to us that professional working relationships and relational trust (Bryk \& Schneider, 2003) were strong across the cases. Professional relationships characterized by high levels of relational trust, reciprocity, 
and collaboration. Moreover, these professional relationships were built with a shared focus on enabling student success. Establishing purposeful relationships was an ongoing intentional high priority for the superintendency teams in this study. Efforts in this direction are supported by evidence from several recent studies (Bryk \& Schneider, 2002; Louis \&Wahlstrom, 2012; Robinson, 2011; Timperley, 2011; Wahlstrom et al., 2010a, 2010b).

Two claims from this existing research were particularly well linked to the evidence we gathered. First, Louis and Wahlstrom (2012) found that "leadership practices targeted directly at improving instruction have significant effects on teachers' working relationships and indirectly on student achievement" and that "when principals and teachers share leadership, teachers' working relationships are stronger and student achievement is higher" (p. 25). The effect occurs "largely because effective leadership strengthens professional community, a special environment within which teachers work together to improve their practice and improve student learning" (p. 25). Similarly, Timperly (2011) underlined the importance professional learning community, which she described as a group of professionals committed to working together to learn about their practice for the purpose of improving student learning. Significantly, it is important for educators in this arrangement to focus on student learning through respectful, trusting relationships and collaborative inquiry for deep learning based on evidence.

\subsubsection{Theme Eight: Accessing External and Internal Expertise}

All six of the districts in this study utilized external expertise to grow capacity and to develop local expertise, particularly the areas of research based instruction, assessment, and instructional leadership. Access to experts was a critical component of ongoing professional learning. External experts were often asked to support district efforts in areas of specific needs. For the most part this expertise was very targeted and purposeful while still allowing for some individuality at the school level. Particularly, in rural districts where access to a cadre of internally trained facilitators or researchers is limited, external experts provided support to the superintendency team.

Though many professional learning opportunities were facilitated internally in the CBE, Alberta's largest district has also benefited from a continuing partnership with the Galileo Educational Network (GENA) at the University of Calgary. Sharon Friesen, Candace Saar, and others on the GENA team have worked extensively to foster pedagogical leadership and they are now helping to strengthen shared instructional leadership across the system through their monthly work with 700 learning leaders from across the system.

When experts were integrated into professional learning, the districts worked to ensure there was continuity and alignment with the priorities of the district, especially with the focus on student learning and building instructional leadership capacity. In keeping with a philosophy of professional learning grounded in work, follow-up with the experts or members of the superintendency team or school leaders was part of the planning and implementation process. Cross-case theme eight - accessing external and internal expertise - illustrates several ways that highly successful and learning focused school districts were working with trusted experts to help build leadership, pedagogy, and assessment. These efforts are supported by recent research by a number of scholars (for instance, Friesen, 2009: Friesen \& Lock, 2010; Hatano \& Oura, 2003; Hargreaves \& Fullan, 2012; Robinson, 2011; Timperley, 2011, Timperley, Wilson, Barrar, \& Fung, 2007). In our view, the larger intent of these district efforts to build internal capacity is to develop what Timperley (2011) describes as adaptive expertise, which is characterized by deep pedagogic or leadership knowledgeable that can be retrieved, organized, and applied to address shifting challenges and needs.

\subsubsection{Theme Nine: Travelling the Pathways of Collaborative Leadership Learning}

In addition to what participants said about their work to build collaborative leadership learning structures and communities within their settings, we also mined data from other interview segments. In particular, responses related to the focus on learning, system-wide efficacy, leadership for learning, and professional learning portions of the interview protocol yielded rich insights to inform theme nine.

The variety of approaches to leadership learning observed in our study support the view that there is no one best way to become a more competent school or district leader. No standardized template dictates a one size fits all mandate for leadership development. Rather, our study suggests that districts enable and benefit from multiple forms of leadership learning.

These highly successful and learning focused districts were committed to development of instructional leaders in every school and at the central office. Each district was on its own journey of collaborative leadership learning. It could be said they were on a continuum of development. Some were fully engaged in instructional leadership while others were not as far along the path, but all were committed to focusing on student learning. Some were very tightly coupled with a model guiding their actions, while other were more loosely coupled bound together 
by a shared vision but more flexible in how individual schools approached implementing a strong focus on student learning and providing instructional leadership.

Although there were multiple pathways, there were common strategies employed to move in the direction of collaborative leadership community building. Each district had organizational structures that enabled collaboration, leadership and alignment, such as: classroom support teachers, learning coaches, instructional leadership teams, professional learning communities, administrative meetings, beginning administrator or teacher programs. Collaboration, mentorship and adequate resources, including time, were evident in each opportunity. Processes were in place that also built capacity like engagement in research or implementation of specific programs or models. Each district recognized prior learning and created a scaffold to new learning. Districts recognized that having only a few priorities all focused on student learning was a leverage point that energizes people to work together.

Our final cross-case theme - travelling the pathways of collaborative leadership learning - draws attention to the multiplicity of ways that the superintendents in this study capitalized on the benefits of collective, shared, and distributed leadership to foster enhanced leadership capacity and to support aspiring and novice leaders in their systems. Their collaborative orientation leverages collective efforts to support overall instructional leadership that scaffolds teaching directed toward student success. This work is supported by a number of studies (for instance, Anderson \& Louis, 2012; Barber, Whelan, \& Clark, 2010; Elmore \& Burney, 1999; Leithwood; 2008, 2010a, 2011, \& 2012; Louis, Leithwood, Anderson, \& Wahlstrom, 2010a, 2010b; Louis and Wahlstrom, 2012; McLaughlin \& Talbert, 2003; Robinson, 2011; Timperley, 2011; Togneri \&Anderson's, 2003; Wahlstrom, Louis, Leithwood, \& Anderson, 2010a, 2010b). The theme also supports the Togneri and Anderson (2003) finding that most high performing districts provide intensive long-term opportunities for principals to further develop their capacities as instructional leaders.

\section{Implications}

Further analysis of these nine cross-case themes generated five major assertions about the ways in which successful superintendency teams lead educator and student learning. These analytical generalizations are based on the research team's reasoned judgment and assertational logic about the extent to which the findings and themes of this study are transferable and can be used to guide superintendency team practice in other settings. These assertions have been framed as five lessons for superintendency teams who seek to more effectively lead learning in their districts.

6.1 Leadership Lesson One-Framing Leadership Research in Action- is based on our study's first major assertion:

The practices of superintendency teams who lead learning are action-oriented and research informed.

For superintendency teams, the availability of an easily accessible and understandable Alberta Framework grounded in research and steeped in practical wisdom, offers a way to scaffold learning and develop common language to speak with district colleagues. Whether directly informed by the Alberta Framework or by other tools or models, the district leaders in our study did more than just read and conceptualize research - they thoughtfully utilized what they were learning to implement change and to lead learning

6.2 Leadership Lesson Two-Leading through Superintendency Teams-is based on our study's second major assertion:

Superintendents who lead learning share leadership with strong, collaborative, and learning focused senior leadership teams.

Superintendents in highly successful and learning focused districts fully understand the complexities, challenges, and dynamics of their unique leadership positions. Contrary to media popularized notions of heroic leadership, the superintendents in this study capitalize on the benefits of collective, shared, and distributed leadership. Their collaborative orientation leverages collective efforts to support student success at every level - starting with their senior leadership team.

6.3 Leadership Lesson Three - Building Purposeful Professional Relationships - is based on our study's third major assertion:

Superintendency teams that lead learning influence educators at all levels through purposeful professional relationships.

The relational orientations and interpersonal skills of superintendency team members in this study were foundational contributors to student success in their districts. Relational trust emanating from senior leadership encouraged participants at all levels to work effectively together to support learning, engagement, and well being 
of all students and all staff members in district. Professional conversations were most often characterized by respect and challenge, summoning the best available pedagogical, content, and assessment knowledge to keep the best interests of student learning, engagement, and well-being of students at the centre.

6.4 Leadership Lesson Four - Accessing External and Internal Expertise - is based on our study's fourth major assertion:

Superintendency teams that lead learning access external and internal expertise to build adaptive professional capacity through all layers of the system.

Learning focused superintendency teams thoughtfully integrate internal and external expertise to grow professional capacity. Four of the six districts profited from their ongoing connections with external experts who undertook targeted professional learning in such strategically significant areas as instructional leadership, engaging pedagogy, and student assessment. The larger purpose of these partnering relationships was to build adaptive professional expertise in teachers, school leaders, and central office leaders.

6.5 Leadership Lesson Five - Travelling the Pathways of Collaborative Leadership Learning - is based on our study's fifth major assertion:

Superintendency teams that lead learning employ multiple capacity building approaches to leadership learning in their districts.

The evidence is clear - educational leadership is second only to teaching in its impact on student learning. The research is also definitive about the benefits of collective, shared, and distributed leadership. At a time of significant social turbulence and rapid generational turnover in the principalship, it is vitally important that these collaborative orientations guide leadership learning and development. Superintendency teams in all six cases are supporting a variety of leadership development pathways to better serve the professional learning needs of aspiring and current leaders. Leadership learning in these districts is increasingly based on research derived frameworks in authentically engaging professional leadership learning communities that are informed by evidence of impact on teaching and learning.

\section{Scholarly Significance}

Our study illustrates how superintendency teams lead learning in three ways. First, it provides six detailed descriptions of the work of superintendency teams in six school districts. Each case summary stands as one contextualized set of approaches used by a superintendency team in its specific geographic, social, economic, and educational setting. Second, the first five of the nine cross-case themes provide evidence of the power of the five dimensions of our conceptual framework - these dimensions do, in fact, enable district leaders to frame leadership research in action. Cross-case themes six through nine speak to the overwhelmingly positive impact of evidence informed practice, judicious use of expertise, and collaborative leadership learning at the district level.

Case studies such as this one aim to be generalizable to theoretical propositions and not to populations or universes as in statistical generalization (Yin, 2009, p. 15). We offer the five lessons for superintendency teams from the perspective that "most fields informed by the social sciences have imperfect evidence available to inform their practices" and, as such, "judgments are rightly based on the best available evidence, along with the practical wisdom of those actually working in the field (Leithwood, Louis, Anderson \& Wahlstrom, 2004, p. 9).

\section{References}

Alberta Education. (2010). Inspiring education. Edmonton, AB: Alberta Government.

Alberta Education. (2013). Ministerial order on student learning. Edmonton, AB: Alberta Government.

Anderson, S., \& Louis, K. S. (2012). The district difference: A new perspective on the local challenges for improvement. In K. Leithwood \& K. Seashore Louis (Eds.), Linking Leadership to student learning (pp. 181-202). San Francisco: Jossey-Bass.

Andres, L. (2012). Designing and doing survey research. Thousand Oaks, CA: Sage. https://doi.org/10.4135/9781526402202

Bandura, A. (1977). Self-efficacy: Toward a unifying theory of behavioral change. Psychological Review, 84, 191-215. https://doi.org/10.1037/0033-295X.84.2.191

Bandura, A. (1986). Social foundations of thought and action: A social cognitive theory. Upper Saddle River, NJ: Prentice Hall.

Bandura, A. (1989). Human agency in social cognitive theory. American Psychologist, 44(9), 1175-1184. https://doi.org/10.1037/0003-066X.44.9.1175 
Bandura, A. (1997). Self-efficacy: The exercise of control. New York, NY: W. H. Freeman.

Barber, M., Whelan, F., \& Clark. M. (2010). Capturing the leadership premium: How the world's top school systems are building capacity for the future. Retrieved from http://www.mckinsey.com/clientservice/social_sector/our_practices/education/knowledge_highlights/ /med ia/Reports/SSO/schoolleadership_final.ashx

Brandon, J., Hanna, P., \& Negropontes, D. (2014a). Superintendents who lead learning. Paper presented at the American Educational Research Association Annual Meeting, Philadelphia, PA.

Brandon, J., Hanna, P., \& Negropontes, D. (2014b). Superintendents who lead learning. Paper presented at the College of Alberta School Superintendents Fall Conference, Calgary, AB.

Brandon, J., Hanna, P., Morrow, R., Rhyason, K., \& Schmold, S. (2013). The Alberta framework for school system success. Edmonton, AB: Henday Publishing.

Bransford, J., Brown, A., \& Cocking, R. (2000). How people learn: Brain, mind, experience and school. Washington, DC: National Academies Press.

Bredeson, P., \& Johansson, O. (2000). The school principals' role in teacher professional development. Journal of In-Service Education, 26(2), 385-401. https://doi.org/10.1080/13674580000200114

Brinkman, S., \& Kvale, S. (2015). Interviews: Learning the craft of qualitative research interviewing. Los Angeles, CA: Sage.

Bryk, A., \& Schneider, B. (2002). Trust in Schools: A core resource for improvement. New York: Russell Sage.

Cawelti, G. (2001). Six districts, one goal of excellence. Journal of Staff Development, 22(4), 31-35.

Creswell, J. (2007). Qualitative inquiry and research design: Choosing among five approaches (2nd ed.). Thousand Oaks, CA: Sage.

Creswell, J. (2012). Educational research: Planning, conducting, and evaluating quantitative and qualitative research. Boston, MA: Pearson Education, Inc.

Darlington-Hammond, L., Hightower, A., Husbands, J.L., LaFors, J.R., Young, V. M., \& Christopher, C. (2003). Building instructional quality and coherence in San Diego city schools: System struggle, professional change. Retrieved July 2008, from http://depts.washington.edu/ctpmail/PDFs/Brief_nine.pdf

Elmore, R., \& Burney, D. (1998). Continuous improvement in Community District \#2, New York City. Retrieved July 2008, from www.lrdc.pitt.edu/hplc/hplc.html

Firestone, W., \& Riehl, C. (2005). A new agenda for research in educational leadership. New York: Teachers College Press.

Friesen, S., \& Lock, J. (2010). High performing school systems in the application of 21st century learning technologies: Review of the research. Calgary, AB: University of Calgary.

Fullan, M. (2001). Leading in a Culture of Change. San Francisco, California: Jossey-Bass.

Fullan, M. (2011). The moral imperative realized. Thousand Oaks, CA: Corwin.

Fullan, M. (2014). The principal: Three keys to maximizing impact. San Francisco: Jossey-Bass.

Gordon, M., \& Louis, K. S. (2012). Linking parent and community involvement with student achievement. In K. Leithwood \& K.S. Louis (Eds.). Linking leadership to student learning. San Francisco: John Wiley \& Sons, Inc.

Guskey, T. (1998). The age of our accountability. Journal of Staff Development, 19(4), 36-44.

Hallinger, P. (2003). Leading educational change: reflections on the practice of instructional and transformational leadership. Cambridge Journal of Education, 33(3), 329-352. https://doi.org/10.1080/0305764032000122005

Hargreaves, A., \& Fullan, M. (2012). Professional capital: Transforming teaching in every school. New York: Teachers College Press.

Hargreaves, A., \& Shirley, D. (2012). The global fourth way: The quest for educational excellence. Thousand Oaks, CA: Corwin.

Hargreaves, A., \& Shirley, D. (2012). The international quest for educational excellence: Understanding Canada's high performance. Education Canada, 52, 10-13. 
Hargreaves, A., Crocker, R., Davis, B., McEwen, L., Sahlberg, P., Sumara, D., ... Hughes, M. (2009). The learning mosaic: A multiple perspectives review of the Alberta Initiative for School Improvement. Edmonton, AB: Alberta Education.

Hatano, G., \& Oura, Y. (2003). Commentary: reconceptualising school learning, using insight from expertise research. Educational Researcher, 32, 26-29. https://doi.org/10.3102/0013189X032008026

Hattie, J. (2009). Visible learning: A synthesis of over 800 meta-analyses relating to achievement. New York, N.Y: Routledge.

Hattie, J. (2012). Visible learning for teachers: Maximizing impact on learning. New York, N.Y: Routledge.

Hightower, A.M. (2002). San Diego's big boom: District bureaucracy supports culture of learning. Retrieved July 2008, from http://depts.washington.edu/ctpmail/PDFs/SanDiego-AH-01-2002.pdf

Leithwood, K., \& Louis, K.S. (2012). Linking leadership to student learning. San Francisco: John Wiley \& Sons, Inc.

Leithwood, K. (2008). Evidence-based characteristics of high performing school districts. Paper presented at the Moving and Improving Symposium, College of Alberta School Superintendents, Edmonton, AB.

Leithwood, K. (2010). Turning around underperforming school systems: Guidelines for district leaders. Paper prepared for the College of Alberta School Superintendents, Edmonton, AB.

Leithwood, K. (2010a). Characteristics of school districts that are exceptionally effective in Closing the Achievement Gap. Leadership and Policy in Schools, 9(3), 245-291. https://doi.org/10.1080/15700761003731500

Leithwood, K. (2011). District Effectiveness Framework. Paper presented at the Annual Pre-Conference of the College of Alberta School Superintendents. Edmonton, AB: College of Alberta School Superintendents.

Leithwood, K. (2012). Core practices: The four essential components of the leader's repertoire. In K. Leithwood \& K. Seashore Louis (Eds.), Linking Leadership to student learning (pp. 57-67). San Francisco: Jossey-Bass.

Leithwood, K. Aitken \& Jantzi, D. (2006). A review of transformational school leadership research. Paper presented at American Educational Research Association, Montreal, PQ.

Leithwood, K., Anderson, S., \& Louis, K.S. (2012). Principal efficacy: District-led professional development. In K. Leithwood \& K. Seashore Louis (Eds.), Linking Leadership to student learning (pp. 119-141). San Francisco: Jossey-Bass.

Leithwood, K., Louis, K.S., Anderson, S., \& Wahlstrom, K. (2004). Review of Research: How Leadership Influences Student Learning. New York: The Wallace Foundation.

Leithwood, K., Louis, K.S., Anderson, S., \& Wahlstrom, K. (2010). Learning from Leadership: Investigating the links to improved student learning. New York: The Wallace Foundation.

Levin, B. (2001). Reforming education: From origins to outcomes. New York: RoutledgeFalmer.

Levin, B. (2008). How to change 5,000 schools: A practical and positive approach for leading change at every level. Cambridge, MA: Harvard Education Press.

Levin, B. (2010). Global voices in Canada: Education improvement in Alberta. Phi Delta Kappan, 91(7), 81-82 (online only). https://doi.org/10.1177/003172171009100720

Louis, K.S., \& Wahlstrom, K. (2012). Shared and instructional leadership: When principals and teachers successful lead together. In K. Leithwood \& K. Seashore Louis (Eds.), Linking Leadership to student learning (pp. 25-41). San Francisco: Jossey-Bass.

Louis, K.S., Leithwood, K., Anderson, S., \& Wahlstrom, K. (2010a). Learning from leadership: Investigating the links to improved student learning. New York: The Wallace Foundation.

Louis, K.S., Leithwood, K., Anderson, S., \& Wahlstrom, K. (2010b). Key findings: Learning from leadership: Investigating the links to improved student learning. New York: The Wallace Foundation.

Maguire, P. (2003). District practices and Student Achievement: Lessons from Alberta. Society for the Advancement of Excellence in Education.

Marzano, R., \& Waters, T. (2006). School district leadership that works: The effect of superintendent leadership on student achievement. A working paper for McRel Publishing. 
Marzano, R., \& Waters, T. (2009). District leadership that works: Striking the right balance. Bloomington, IN: Solution Tree Press/McRel Publishing.

McCormick, M. J. (2001). Self-efficacy and leadership effectiveness: Applying social cognitive theory to leadership. The Journal of Leadership Studies, 8(1), 22-33. https://doi.org/10.1177/107179190100800102

McLaughlin, M., \& Talbert, J. (2003). Reforming districts: How districts support school reform. Retrieved July 2008, from http://depts.washington.edu/ctpmail/Reports.html\#Reforming

Merriam, S. (1998). Qualitative research and case study applications in education. San Francisco: Jossey-Bass Publishers.

Miles, M., Huberman, A., \& Saldana, J. (2014). Qualitative data analysis. A methods sourcebook. Thousand Oakes, CA: Sage Publications.

Opfer, D., Pedder, D., \& Lavicza, Z. (2011). The influence of school orientation to learning on teachers' professional learning change. School Effectiveness and School Improvement: An International Journal of Research, Policy and Practice, 22(2), 193-214. https://doi.org/10.1080/09243453.2011.572078

Organization for Economic Co-operation and Development (OECD) (2001). Schooling for tomorrow: What schools for the future?. Retrieved May 9, 2009, from http://www.oecd.org/dataoecd/56/39/38967594.pdf

Organization for Economic Cooperation and Development (OECD) (2007). Understanding the brain: The birth of a learning science. Paris, FR: The Organization of Economic Cooperation and Development.

Organization for Economic Cooperation and Development (OECD) (2008). Innovating to learn: Learning to innovate. Paris, FR: The Organization of Economic Cooperation and Development.

Pritchard, R., \& Marshall, J. (2002). Professional development in "healthy" vs. "'unhealthy" districts: Top 10 characteristics based on research. School Leadership and Management, 22(2), 113-41. https://doi.org/10.1080/1363243022000007719

Resnick, L. B., \& Harwell, M. (2000). Instructional variation and student achievement in a standards-based education district. Retrieved July 2008, from http://www.cse.ucla.edu/products/Reports/TECH522.pdf

Robinson, V. (2011). Student-centered leadership. San Francisco: Jossey-Bass.

Robinson, V., Lloyd, C., \& Rowe, K. (2008). The impact of leadership on student outcomes: An analysis of the differential effects of leadership types. Educational Administration Quarterly, 44(5), 635-674. https://doi.org/10.1177/0013161X08321509

Ryan, J. (2006). Inclusive leadership. San Francisco: Jossey-Bass.

Sawyer, K. (2006). The Cambridge handbook of the learning sciences. New York, NY: Cambridge University Press.

Sawyer, R.K. (2008). Optimizing learning: Implications of learning sciences research. In OECD (Ed.), Innovating to learn: Learning to innovate. Centre for Research and Innovation: OECD. pp. 45-62. https://doi.org/10.1787/9789264047983-4-en

Schmold, S., \& Morrow, R. (2009b). Moving and improving: Building leadership capacity project report and evaluation. Edmonton, AB: The College of Alberta School Superintendents.

Schmold, S., \& Morrow, R. (2009). A framework for school system success. Edmonton, AB: The College of Alberta School Superintendents.

Stake, R. (1995). The art of case study research. Thousand Oakes, CA: Sage Publications.

Stake, R. (2006). Multiple case study analysis. New York: The Guilford Press.

Steele, L. (2010). Boundary crossing in rural districts: Reconceptualizing the roles of rural midlevel leaders. Unpublished doctoral dissertation, University of Calgary.

Timperley, H. (2011). Realizing the power of professional learning. London: Open University Press.

Timperley, H., Wilson, A., Barrar, H., \& Fung, I. (2007). Teacher professional learning and development: Best evidence synthesis iteration (BES). Wellington, New Zealand: Ministry of Education.

Togneri, W., \& Anderson, S.E. (2003). Beyond islands of excellence: What districts can do to improve instruction and achievement in all schools. Retrieved July 2008, from http://www.learningfirst.org/publications/districts 
Townsend, D., \& Adams, P. (2009). The essential equation: A handbook for school improvement. Calgary: Detselig Press.

Wahlstrom, K. (2012). An up-close view of instructional leadership: A grounded analysis. In K. Leithwood \& K. Seashore Louis (Eds.), Linking Leadership to student learning (pp. 68-86). San Francisco: Jossey-Bass.

Wahlstrom, K., Louis, K.S., Leithwood, K., \& Anderson, S. (2010). Executive summary of the research findings. Learning from leadership: Investigating the links to improved student learning. New York: The Wallace Foundation.

Wahlstrom, K., Louis, K.S., Leithwood, K., \& Anderson, S. (2010b). A synthesis of implications for policy and practice from Learning from leadership: Investigating the links to improved student learning. New York: The Wallace Foundation.

Wallace Foundation. (2010). Key findings: Learning from leadership: Investigating the links to improved student learning. New York: The Wallace Foundation.

Whelan, F. (2009). Lessons learned: How good policies produce better schools. London: MPG Books.

Willms, D., Friesen, S., \& Milton, P. (2009). What did you do in school today? Transforming classrooms through social, academic and intellectual engagement. Toronto, ON: Canadian Education Association.

Wood, R. E., \& Bandura, A. (1989). Impact of conceptions of ability on self-regulatory mechanisms and complex decision making. Journal of Personality and Social Psychology, 56(3), 407-415. https://doi.org/10.1037/0022-3514.56.3.407

Yin, R. (2009). Case study research. Design and methods. Thousand Oakes, CA: Sage Publications.

\section{Copyrights}

Copyright for this article is retained by the author(s), with first publication rights granted to the journal.

This is an open-access article distributed under the terms and conditions of the Creative Commons Attribution license (http://creativecommons.org/licenses/by/4.0/). 